\title{
Exploring the Influence of Job Stress on Job Performance: Mediated By Emotional
}

\section{Intelligence in Educational Context}

\author{
* Dr. Muhammad Idris, Assistant Professor (Corresponding Author) \\ ** Muhammad Saqib Khan, Lecturer \\ *** Mati Ullah Khan, Lecturer
}

\begin{abstract}
The job performance is vital phenomenon in the context of education sector as educational institutions might be able to obtain desired ranking only when the employees are motivated to show their best performance. There are many hindrances which are responsible to affect the employees' performance and institutions wherein job stress is more critical. The stressed employees are not only burnout form their job but also effect their level of the performance. In this situation, "the role of emotional intelligence" is vital in determining the employees' attitude to show their best performance. The data was collected from faculty member hailing from higher institutions and analyzed through statistical procedures to find answers of research questions. The results are significant and expected to be valuable to management of the higher institutions in revisiting their policies concerning the research issues under considerations. Some recommendations have also been extracted from the results of the study.
\end{abstract}

Keywords: Job Stress, Job Performance, Emotional Intelligence, Educational Institutions Introduction

The educational institutions are more exposed to the phenomenon of performance as these institutions are greatly concerned with their academic standards and ranking which are only possible through the increased level of performances. The higher institutions are also need the "effective performance management system" to meet the demands of stakeholders and to cater their desired ranking in the competitive environment (Griffin, Neal \& Neale, 2001). These institutions are more concerned with performance parameters who are effective in gauging and augmenting performance standards optimistically as well as those constrains which affect the desired performance undesirably (Bartram \& Casimir, 2006). Therefore, performance has been measured as significant tool in determining the success of academic institutions (Thomas \& Feldman, 2009). Similarly, performance is also vital for employees in obtaining their desired status as the professional status of employees in contingent on their level of efforts and performance (Asif \& Searcy, 2013). However, there are certain dynamic factors which directly influences the performance undesirably in which job stress is more corrosive.

The job stress is researched widely and have destructive influence on employees' health and performance which directly influences the institutional performance. The institutions are always looking for exploring main factors that are responsible in deteriorating performance of their employees and institution (Beehr \& Glazer, 2005). The job stress in mainly originates from undesirable events and unfair decisions which affects the employees' perceptions about the prolonged stay and higher efforts that concerned employees show at workplace (Beehr, Jex \& Ghosh, 2001). The employees when experiences job burnout and stress at wider scale are expected to show lesser efforts and performance in comparison to those who are slightly exposed to the issues of job stress (Ahmad, Zarina, Rima, Natasha \& Normazwin, 2012). The job stress not only influences performance, but it affects employees' commitment and job satisfaction. In this situation, employees are required to have strong psychological support and intelligence to cater the situation and to meet their desired standing

\footnotetext{
* Department of Education, Abdul Wali Khan University Mardan (AWKUM), KP, Pakistan

** Department of Business Administration, Gomal University, Dera Ismail Khan, Pakistan

***Institute of Education \& Research, University of Lakki Marwat, KP, Pakistan
} 
(Arshadi \& Damiri 2013). Here the role of emotional intelligence is more effective in determining the attitude of employees.

The emotional intelligence is vital for the employees as the employees who are intelligent emotionally are predictable to handle the undesirable events in effective manner to produce the desired outcomes (Brackett \& Mayer, 2003). The emotional intelligence is vital for the employees in managing their routine affairs in artistic manners to cater the situations and to meet the undesirable events which are concerned with the employee's worries about their professional tenure that directly influences effective performance (Ciarrochi, Deane \& Anderson, 2002). The employees who are intelligent emotionally are expected to solve their issue in effective manners concerning the job stress and burnout leading to psychological stress. Similarly, the employees are always detained to preserve their worries about the dissatisfaction at the workplace which directly influence their efforts and performance in destructive manners (King \& Gardner, 2006). These are the main issues that the employees' experiences while performing their responsibilities in efficient and effective manners (Vibhor, Smrita \& Prachi, 2020). The employees concern about their job are regularly and effectively communicated and their apprehensions are respected in institutions.

\section{Problem Statement}

The job stress is the critical issue which disturbs the concerned employees' performance however, relationships between job performance and job stress can be facilitated through the emotional intelligence when applied effectively. The foremost theme of current study is related to study the effects of the job stress and job performance mediated by emotional intelligence among faculty members hailing form higher educational context in Khyber Pakhtunkhwa, Pakistan.

\section{Literature Review}

The existing research offers an insight about the job performance and job stress in different context as well in educational context with diverse outcomes. However, still the research is required to survey the job stress concerning the job performance (Ali, Raheem, Nawaz \& Imamuddin, 2014). Similarly, numerous mediators have been used to observe the relations between job performance and job stress. The job stress is critical for the higher institutions as the stressed employees might not be able to achieve their assigned tasks effectively (Alsharm, 2005). Similarly, the stressed employees are likely to show lower performance and declined commitment due their psychological pressure as originate from undesirable eventualities (Chandhok \& Tyagi, 2012). The emotional intelligence is vital as emotionally intelligent employees are likely to produce maximum outcomes whatsoever, they faced the stressful situations (Dar, Naseem, Akmal \& Khan, 2011). The job stress at workplace is likely to influence the job performance however, it can be controlled to some extent through the emotional intelligence in the institutions (Kholifat \& Almatarneh, 2010). Therefore, these are the most critical issue that may hamper the credibility, ranking and success of the academic institutions.

\section{Job Stress}

Stress in a dynamic factor that affects the routine life of the individuals as well as the life of the professionals at the workplaces. The stress results in increased job burnout and decrease performance and thus further results in decrease commitment and increase psychological pressure (Chandhok \& Tyagi, 2012). The job stress is mainly related with the undesirable actions/events that concerned individuals never expect from the professional affiliations. The job stress is also critical for employees as it hurdles in showing the utmost potential and required performance (Gillespie, Walsh, Dua \& Stough, 2001). The job stress is important for the higher institutions as it is mainly related to affect the status and ranking of the academic institutions. The stressful situation is critical for workplace as it disturb the entire working format of organizations (Ismail, Suh, Ajis \& Dollah, 2009). The employees who are stressed are experiences unwanted events that they never expect from their job. Therefore, job stress not only affects the employees' performance at workplace but also affects the success of concerned institutions (Kazmi, Amjad \& Khan, 2008). Thus, the job stress has been widely considered as dilemma for the employees and institutions in higher as well as improved performances.

\section{Job Performance}

The job performance is the critical success factor for all institutions whether public as well as private since the institutional success in hinges upon the successful presentation of the performance that the institutions expect from their employees. The employees' efforts and performance are the actual results of institutional performance (Chandhok \& Tyagi, 2012). The institutions those who are 
successful in managing their performance are considered as the effective institutions (Ismail, Ajis, Suh, \& Dollah, 2009). In similar vein, the institutions who are active in managing the employees' apprehensions are considered are the most active institutions in modern viable situations (Kholifat \& Almatarneh, 2010). Consequently, the employees' performance is actually hampered by the undesirable eventualities at the workplace which is the outcome of what the employees are not expecting from concerned institution (Kotteeswari \& Sharief, 2014). The employees' performance is also supported through the emotional intelligence as the employees who are psychologically intelligent are able to manage their credentials at par to the required standards which further cannot be influenced by other dynamic factors in the concerned institution.

\section{Emotional Intelligence}

The emotional intelligence is dynamic for organizations and employees as the organization need the services of those employees and professionals who are emotionally intelligent to manage the institutional affaires more deliberately while it is vital for the employees since it enables the employees in managing their routine affairs and in dealing with all the kinds of situations (Soran, Balkan \& Serin, 2014). It not only influences the employees' efforts and potentials positively but also "have significant impact on the" performance and commitment (Ismail, Ajis, Suh, \& Dollah, 2009). The emotional intelligence is also significant for the institutions as it enables concerned institution in managing their institutional deeds through the concerned employees more efficiently and effectively (Anand, Ali, Panwar \& Singhal, 2019). Thus, institutions and employees both needs the emotional intelligence phenomenon to cater the situations and to meet the desired objectives more effectively (Davar \& Singh, 2014). The institutions also need the emotionally intelligent employees to achieve their anticipated goals and to achieve their desired tasks more systematically as it is the dire need of every institutions to manage their affairs artistically.

\section{Job Stress, Emotional Intelligence \& Job Performance}

The job stress is critical phenomenon towards the job performance of the employee as higher the job stress, lower might be the performance level. The employees who are stressed but emotionally strong and intelligent are likely to manage the situations as per the mandatory standards (Ismail, Suh, Ajis \& Dollah, 2009). The employees job performance is the most successful parameter for concerned institution to gauge the employees' skills and knowledge as it is mostly related with the skills and efforts required for the particular job (Soran, Balkan \& Serin, 2014). The employees who are emotionally intelligent are expected to manage their workplace events more successfully due to their desired and manageable opportunities for their successful operations at the workplace (Anand, Ali, Panwar \& Singhal, 2019). The emotional intelligence provides new prospects to the employees to handle the undesirable situation and to manage their activities intelligently to attain the desired outcomes (Kholifat \& Almatarneh, 2010). It is also important for the institutions in managing the teaching and learning activities more significantly and to achieve the desired goals more successfully to attain the desired standing and ranking in competitive situations.

Figure 1 Theoretical Framework

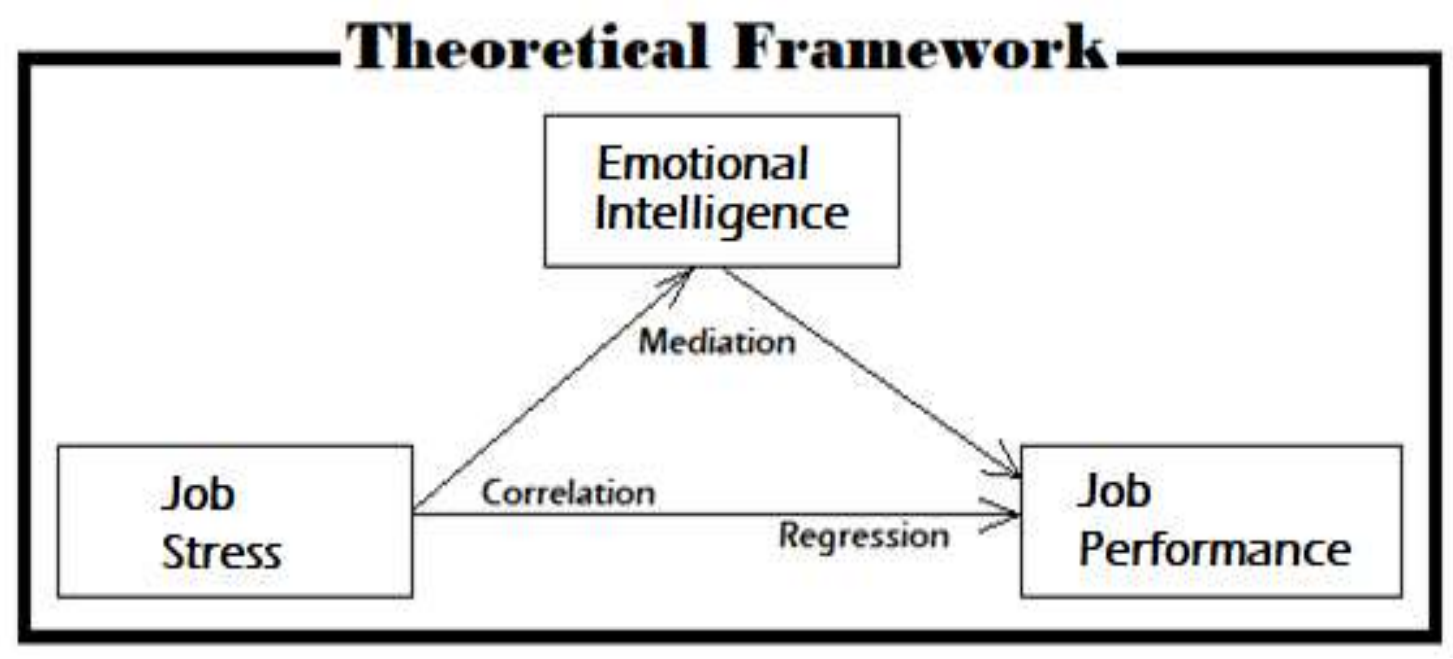




\section{Research Hypotheses}

H1: There is positive and significant association "between the independent and dependent variables".

H1: The "independent variable has significant" impact on the dependent variable of research study.

H3: The emotional intelligence significantly mediates the relationship "between job stress and job performance".

\section{Research Methodology}

The appropriate methods are procedures are prerequisite to conduct study systematically and to reach the conclusion. In this connection, the survey approach was used to access the sample of the population. the population of study comprises the faculty members of Abdul Wali Khan University Mardan (537) while a sample (145) has been drawn/selected from the population over statistical formula (Yamani, 1679). Therefore, total 145 questionnaires were distributed wherein 136 were recollected. The literature has been collected through "secondary sources" while the primary data was "collected through questionnaire". The data was analyzed through different statistical procedures. The questionnaire was adapted from the existing research studies and its reliability was quite satisfactory. The variables were measured through 11 items for each variable and 5-point Likert scale was used.

Table 1 Reliability Statistics

\begin{tabular}{lcc}
\hline \multicolumn{1}{c}{ Research Variables } & Items & Alpha Cronbach \\
\hline Job Stress & 11 & .810 \\
Job Performance & 11 & .741 \\
Emotional Intelligence & 11 & .782 \\
Instrument & 33 & .886 \\
\hline
\end{tabular}

\section{Results and Discussion}

The analysis of data is an important part of research studies. The study results as obtained over statistical procedures have been presented in this section so as to better comprehend the statistical relationships among research variables under study to reach the objectives and to further reach the conclusion.

Table 2 Descriptive Statistics

\begin{tabular}{lccccc}
\hline & N & Minimum & Maximum & Mean & Std. Deviation \\
\hline Job Stress & 136 & 1.00 & 4.00 & 2.7592 & .82350 \\
Job Performance & 136 & 2.00 & 5.00 & 3.5482 & .81663 \\
Emotional Intelligence & 136 & 2.22 & 4.11 & 3.0441 & .43703 \\
Valid N (list-wise) & 136 & & & & \\
\hline
\end{tabular}

Table 3 Correlation Analysis $\left(\mathrm{H}_{3}\right)$

\begin{tabular}{llcc}
\hline & & Stress & Intelligence \\
\hline Job Stress & Pearson Correlation & 1 & $-.455^{* *}$ \\
& Sig. (2-tailed) & & .000 \\
Emotional Intelligence & $\mathrm{N}$ & 136 & 136 \\
& Pearson Correlation & $-.455^{* *}$ & 1 \\
& Sig. (2-tailed) & .000 & \\
Job Performance & $\mathrm{N}$ & 136 & 136 \\
& Pearson Correlation & $-.668^{* *}$ & $.726^{* *}$ \\
& Sig. (2-tailed) & .000 & .000 \\
& $\mathrm{~N}$ & 136 & 136 \\
\hline
\end{tabular}

The correlation analysis concerning the first hypothesis shows the significant information in deciding the association among research variables. The results further show that job stress is significantly but associated negatively with job performance (-.668 \& .000), emotional intelligence is negative but significantly associated job stress (-.455), however, "emotional intelligence is positively and significantly associated with job performance" of the employees in the selected higher institutions. Therefore, the hypothesis \# 1 about association is thus rejected. The results are supported from the existing research studies (Yusoff, Khan \& Azam, 2013; Yu \& Wu, 2011; Gilboa, Shirom, Fried \& Cooper, 2008).

Table 4 Regression Analysis $\left(\mathrm{H}_{2}\right)$ (Model Summary)

\begin{tabular}{ccccc}
\hline Model & $\mathbf{R}$ & R Square & Adjusted R Square & Std. Error of Estimate \\
\hline 1 & $.819^{\mathrm{a}}$ & .671 & .666 & .47202 \\
\hline
\end{tabular}


Table 5 Regression Analysis $\left(\mathrm{H}_{2}\right)$ (ANOVA)

\begin{tabular}{llccccc}
\hline & Model & Sum Squares & df & Mean Square & F & Sig. \\
\hline 1 & Regression & 60.397 & 2 & 30.198 & 135.537 & $.000^{\mathrm{b}}$ \\
& Residual & 29.633 & 133 & .223 & & \\
& Total & 90.030 & 135 & & & \\
\hline
\end{tabular}

Table 6 Regression Analysis $\left(\mathrm{H}_{2}\right)$ (Coefficients)

\begin{tabular}{llccccc}
\hline \multicolumn{1}{c}{ Model } & \multicolumn{2}{c}{$\begin{array}{c}\text { Unstandardized } \\
\text { Coefficients }\end{array}$} & $\begin{array}{c}\text { Standardized } \\
\text { Coefficients } \\
\text { Beta }\end{array}$ & t & & Sig. \\
& & B & Std. Error & . & \\
\hline 1 & (Constant) & 1.693 & .412 & & 4.104 & .000 \\
& Job Stress & -.423 & .055 & -.427 & -7.639 & .000 \\
& Emotional Intelligence & .993 & .104 & .531 & 9.515 & .000 \\
\hline
\end{tabular}

a. $\quad$ Predictors: (Constant), Emotional Intelligence, Job Stress

b. Dependent Variable: Job Performance

The regression procedure was used to examine the impact of the job stress and emotional intelligence upon the job performance wherein the results show 67 percent changes in the job performance is due to the emotional intelligence and job stress while the coefficient show the significant effect of job stress on the job performance $(-.423 \& .000)$ and the emotional intelligence on the job performance (.993 \& .000). Consequently, hypothesis \# 2 is accepted based upon the results obtained from the regression procedure. The results of the results are validated through previous studies results on the same issue in similar as well as in the different context (Yu \& Wu, 2011; Gilboa et al., 2008; Yusoff et al., 2013).

Table 7 Mediation Analysis $\left(\mathbf{H}_{3}\right)$ (Model Summary) (Path-a)

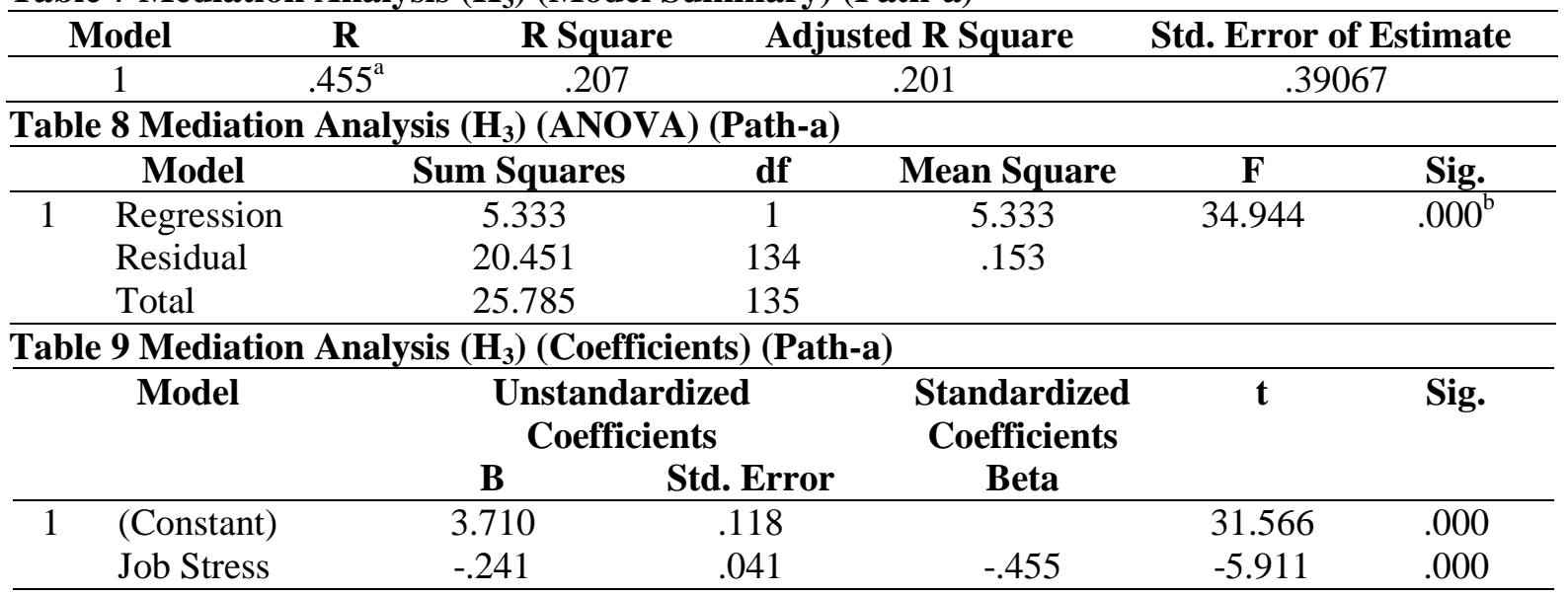

a. $\quad$ Predictors: (Constant), Job Stress

b. Dependent Variable: Emotional Intelligence

The mediation procedure of Barren and Kenny (1986) was used to explore the mediating "role of emotional intelligence" in connecting the job performance and job stress. The first mediation path shows the $21 \%$ change in the emotional intelligence because of job stress. Similarly, the job stress showed the "significant impact on the emotional intelligence" (-0241 \& .000). Consequently, the first mediation path provides significant information concerning the required procedure of mediation.

Table 10 Mediation Analysis $\left(\mathrm{H}_{3}\right)$ (Model Summary) (Path-b, c \& $\left.\hat{\mathbf{c}}\right)$

\begin{tabular}{|c|c|c|c|c|}
\hline Model & $\mathbf{R}$ & R Square & Adjusted R Square & Std. Error of Estimate \\
\hline 1 & $.668^{\mathrm{a}}$ & .447 & .443 & .60965 \\
\hline 2 & $.819^{\mathrm{b}}$ & .671 & .666 & .47202 \\
\hline
\end{tabular}

Table 11 Mediation Analysis ( $\left.\mathrm{H}_{3}\right)$ (ANOVA) (Path-b, c \& $\left.\hat{\mathbf{c}}\right)$

\begin{tabular}{llccccc}
\hline & Model & Sum Squares & df & Mean Square & F & Sig. \\
\hline 1 & Regression & 40.226 & 1 & 40.226 & 108.229 & $.000^{\mathrm{b}}$ \\
& Residual & 49.804 & 134 & .372 & & \\
& Total & 90.030 & 135 & & & \\
2 & Regression & 60.397 & 2 & 30.198 & 135.537 & $.000^{\mathrm{c}}$
\end{tabular}




$\begin{array}{llll}\text { Residual } & 29.633 & 133 & .223 \\ \text { Total } & 90.030 & 135 & \end{array}$

\begin{tabular}{|c|c|c|c|c|c|c|}
\hline \multirow{2}{*}{\multicolumn{2}{|c|}{ Model }} & \multicolumn{2}{|c|}{$\begin{array}{l}\text { Unstandardized } \\
\text { Coefficients }\end{array}$} & \multirow{2}{*}{$\begin{array}{c}\text { Standardized } \\
\text { Coefficients } \\
\text { Beta }\end{array}$} & \multirow[t]{2}{*}{$\mathbf{t}$} & \multirow[t]{2}{*}{ Sig. } \\
\hline & & B & Std. Error & & & \\
\hline \multirow[t]{2}{*}{1} & (Constant) & 5.377 & .183 & & 29.31 & .000 \\
\hline & Job Stress & -.663 & .064 & -.668 & -10.40 & .000 \\
\hline \multirow[t]{3}{*}{2} & (Constant) & 1.693 & .412 & & 4.104 & .000 \\
\hline & Job Stress & -.423 & .055 & -.427 & -7.639 & .000 \\
\hline & Emotional Intelligence & .993 & .104 & .531 & 9.515 & .000 \\
\hline
\end{tabular}

a. Predictors: (Constant), Job Stress, Emotional Intelligence

b. Dependent Variable: Job Performance

The remaining paths of mediation provide significant information in deciding the mediation whether full mediation or partial mediation. The regression procedure provides two models wherein model 1 shows the 45 percent change in the employees' performance is because of job stress and significant "impact of job stress on job performance" (-.663 \& .000). the model 2 shows $67 \%$ change in "job performance is due to job stress" and emotional intelligence with significant impact (-423 \& .000 and $.993 \& .000)$ respectively. The decrease in Beat for job stress in model 1 from (-.663) to (-.423) in model 2 shows that emotional intelligence partially mediates the relationship between job performance and job stress. Thus, the fourth is accepted. The results have been validated through prevailing research studies (Ciarrochi, Deane \& Anderson, 2002; Yusoff et al., 2013; Yu \& Wu, 2011; Gilboa et al., 2008; Soran, Balkan \& Serin, 2014).

\section{Conclusion}

The contemporary literature provides enough evidence about role of job stress in effecting the job performance in different context including higher educational institutions. Likewise, this study examines the same relationships in education context wherein the results provide significant information in deciding the association between job performance and job stress and mediating role of emotional intelligence between job performance and job stress. The results from correlation, regression and mediation provides substantial information about the relationships among the research variables. Therefore, it is concluded that job stress has significant but negative association and effect on job performance. Emotional intelligence has significantly mediated the "relationship between job stress and job performance" done partial mediation. The "results have provided" significant information which are expected to be significant contribution to existing database of knowledge about the issues under study (job stress, emotional intelligence \& job performance. Consequently, some recommendations have been emerged from the results and conclusion of the study.

\section{Recommendations}

$\checkmark \quad$ The job stress has "negative impact on the job performance"; therefore, it is suggested that the institutions should ensure the conducive environment to make the employee happy and satisfied to show their better performances.

$\checkmark \quad$ The job stress "has negative impact on the job performance"; therefore, institutions are required to put more stress on employees' attitude and behavior to make them inspire to show their utmost dedication and performance.

$\checkmark \quad$ The emotional intelligence "has significant impact on the job performance"; therefore, it is suggested that the institutions should maintain the environment and confidence and trust to

\section{References} keep their employees motivated and committed.

Ahmad, H., Zarina I., Faridah I., Rima M. A., Natasha K. \& Normazwin I. (2012) workplace stress and behavior studies of other space: Commercial Complex, Procedia - Social \& behavioral Sciences, 36, pp. 752-769.

Ali, W., Raheem, A., Nawaz, A. and Imamuddin, K. (2014), Impact of Stress on Job Performance: An Empirical study of the Employees of Private Sector Universities of Karachi, Pakistan. International Science Congress Association, 3(7), 14-17. 
Alsharm, S. (2005), Organizational climate relationship with occupational stress for faculty members in Saudi Arabia universities, doctoral thesis, Al-Azhar University. 136.

Anand, D. S., Ali, F., Panwar, D. D., \& Singhal, K. (2019) Analysis of emotional intelligence of bank employees in Dehradun district: a comparative study of private and public sector banks.

Arshadi N. \& Damiri H. (2013) The relationship of job stress with turnover intention and job performance: Moderating role of OBSE, Procedia - Social and Behavioral Sciences, 84, pp.706-710.

Asif, M., \& Searcy, C. (2013). Determining the key capabilities required for performance excellence in higher education. Total Quality Management \& Business Excellence, 25 (1), 22-35.

Bartram, T., \& Casimir, G. (2006). The relationship between leadership and follower in-role performance in higher education institutions. Leadership \& Organization Development Journal, 28 (1), 4-19.

Beehr, T. A. \& Glazer, S. (2005). Organizational role stress. In J. Barling, K. Kelloway, \& M. Frone (Eds.), Handbook of work stress (pp. 7-33). Thousand Oaks, CA: Sage.

Beehr, T.A., Jex, S.M. \& Ghosh, P. (2001). The management of workplace stress. In Johnson, C.M., Redmon, W.K., \& Mahwhinney, T.C. (Eds.), Handbook of Organizational Performance: Behavior Analysis and Management. New York: The Haworth Press.

Brackett, M. A., \& Mayer, J. D. (2003). Convergent, discriminant, and incremental validity of competing measures of emotional intelligence. Personality and Social Psychology Bulletin, 29(9), 1147-1158.

Chandhok, A. \& Tyagi, A. (2012), Impact of Job Stress on Employee's Performance of Sales Department - A Comparative Study of LIC and Bajaj Allianz Life Insurance Company Ltd in the Selected Cities of Haryana. International Journal of Languages, Education and Social Sciences, 13(1), 7-17.

Ciarrochi, J., Deane, F. P., \& Anderson, S. (2002). Emotional intelligence moderates the relationship between stress and mental health. Personality and Individual Differences, 32(2), 197-209.

Ciarrochi, J., Deane, F. P., \& Anderson, S. (2002). Emotional intelligence moderates the relationship between stress and mental health. Personality and Individual Differences, 32(2), 197-209.

Dar, L., Akmal, A., Naseem, M., \& Khan, A. (2011), Impact of Stress on Employees Job Performance in BusinessSector of Pakistan. Global Journal of Management and Business Research, 11 (6), 1- 4.

Davar, S. C., \& Singh, N. (2014). Emotional intelligence \& job performance in banking \& insurance sector in India. The Indian Journal of Industrial Relations, 722-733.

Gilboa, S., Shirom, A., Fried, Y., \& Cooper, C. (2008). A meta-analysis of work demand stressors and job performance: Examining main and moderating effects. Personnel Psychology, 61(2), 227271.

Gillespie, N. A., Walsh, M., Winefield, A. H., Dua, J., \& Stough, C. (2001), Occupational stress in universities: staff perceptions of the causes, consequences and moderators of stress. Work Stress, 15, 53-72.

Griffin, M., Neal, A., \& Neale, M. (2001). The contribution of task performance and contextual Performance to effectiveness: Investigating the role of situational constraints. Applied Psychology: An International Review, 49 (3), 517-533.

Ismail,A., Suh,Y., Ajis, M., Dollah, N.(2009). Relationship between Occupational Stresses, Emotional Intelligence and Job Performance: An Empirical Study in Malaysia". Theoretical and Applied Economics. 3-16.

Kazmi, R., Amjad, S., \& Khan, D. (2008), occupational stress and its effect on job performance a case study of medical house officers of district Abbottabad. J Ayub Med Coll Abbottabad, 20(3), 135-139.

Kholifat, A. \& Almatarneh, S. (2010), The impact of job stress on job performance amongst public school's managers in south Jordan province. Damascus university journal, $26(1+2), 599-642$

Kholifat, A. \& Almatarneh, S. (2010), The impact of job stress on job performance amongst public school's managers in south Jordan province. Damascus university journal, $26(1+2)$, 599642. 
King, M., \& Gardner, D. (2006). Emotional intelligence and occupational stress among professional staff in New Zealand. International Journal of Organizational Analysis, 14(3), 186-203.

Kotteeswari, M. and Sharief, S. (2014), job stress and its impact on performance employees working in bpos: a study. International Journal of advanced research in management, 5(2), 19-27.

Soran, S., Balkan, M., \& Serin, M. (2014), Job stress and performance: the mediating effect of emotional intelligence. European Journal of Business and Social Sciences, 3(5), 67-75.

Thomas, W. H., \& Feldman, C. D. (2009). How broadly does education contribute to job performance? Personnel Psychology, 62, 89-134.

Vibhor, J., Smrita, J., \& Prachi, R. (2020). An analysis for role of emotional intelligence in career success in commercial banks of India. ESPACIOS, 41 (05).

Yu, C., \& Wu, C. (2011). Job stress and job performance among employees in the Taiwanese finance sector: The role of emotional intelligence. Social Behavior and Personality, 39(1), 21-32.

Yusoff, R.M., Khan, A., \& Azam, K. (2013). Job Stress, Performance and Emotional Intelligence in Academia. Journal of Management, 32 (2), 322-336. 